\title{
The Concept of "Availability" in California's Unemployment Insurance Program: Any Reason for Requiring Good Cause?
}

Laid off from leer job as a waitress, a young mother applied for unemployment insurance benefits. Because she could not arrange childcare for her four-year old son on weekends, she informed the Employment Developinent Department of California that she would not be able to accept work on either Saturdays or Sundays. The department denied her benefits on the ground that she was "unavailable" for work, although it did not offer her a job which required work on either of those days; indeed, it offered her no job at all.

The circumstances related above are those of Maria Sanchez. The California Supreme Court prevented an unhappy ending in her case, ${ }^{1}$ finding that slie had "good cause" for restricting her availability, and was thus still "able to work and available for work" within the meaning of section 1253(c) of the California Uneinployment Insurance Code. ${ }^{2}$ The court left for another day, however, the inore difficult questionwhether or not individuals who do not have "good cause" for restricting their availability may still receive benefits. ${ }^{3}$ This Comment addresses that question.

Part I sets out in abridged fashion the goals and general requirements of the California Uneinployment Insurance Program. Part II exammes the "available for work" requireınent ${ }^{4}$ and the "good cause for

1. Sanchez v. Unemployment Ins. Appeals Bd., 20 Cal. 3d 55, 569 P.2d 740, 141 Cal. Rptr. 146 (1977).

2. See Cal. Unemp. INS. CODE § 1253(c) (West 1972). Section 1253(c) provides: "An unemployed individual is eligible to receive unemployment compensation benefits with respect to any week only if the director finds that: . . . (c) He was able to work and available for work for that week." The period of ineligibility following a finding of unavailability is spelled out in 22 CAL. AD. CODE $\S 1253$ (c)-2 (1974) (The claimant is ineligible for the week im which the finding occurs, and remaims "meligible in subsequent weeks until he demonstrates to the satisfaction of the department that he is able to work, available for work and is pursuing a course of action reasonably designcd to result in prompt reemployment in suitable work.")

3. "Good cause" is a term of art in unemployment insurance legislation, and is considered in greater detail at text accompanying and notes 48-49 infra.

4. This type of provision is a feature of virtually all state unemployment compensation laws. UNemployment Service, Manpower Administration, U.S. Dep'T OF Labor, Comparison of STATE UNEMPLoyment INSURANCE LAWs $\$ 410$, at 4-1, Table 400, at 4-23 to 4-24 (Jan. 
reduction" standard and suggests a new criterion for determining an apphicant's "availability" without utilizing the current "good cause" proviso.

\section{UNEMPLOYMENT INSURANCE ${ }^{5}$ IN CALIFORNIA ${ }^{6}$}

\section{A. Goals of the Program}

"Five years of bitter experience with the difficulties and inadequacies of relief [measures]"7 during the Great Depression brought home to Americans the need to make sufficient provision for the unemployed. The unemployment imsurance provisions of the Social Security Act of $1935,{ }^{8}$ passed to stabilize both employment and the economy, ${ }^{9}$ addressed that need. California, as well as the rest of the states and the District of Columbia, mduced in part by tax credits contamed in the Act, ${ }^{10}$ chose to participate im the Act's federal-state system of unein-

1978) [hereinafter cited as CSUIL]. For a general discussion of this aspect of unemployment insurance legislation, see, e.g., R. AltMaN, AvallablLitY For WORK (1950); Freeman, Able to Work and A vailable for Work, 55 YALE LJ. 123 (1945); Comment, "Available for Work" Criterion for Payment of Unemployment Compensation, 30 TEXAS L. Rev. 735 (1952).

5. The terms "unemployınent compensation" and "unemployinent insurance" will be used interchangeably throughout this Comment. Not based on the "means test" of social welfare programs, such as Aid to Families with Dependent Children (AFDC), uneinployment coinpensation or insurance is a form of governmental provision known as social insurance. Some experts use the term "unemployment insurance." See W. Haber \& M. Murray, UNEMPLOYMENT INSURANCE IN THE AMERICAN ECONOMY passim (1966). The House Report that accounpamed the Social Security Act, however, noting that the program is designed "[t]o provide something better than relief on a needs basis for the unemployed," goes on to state that "unemployment coinpensation [is] more counmonly but less accurately called "uneınployment imsurance' . . . ." H.R. REP. No. 615, 74th Cong., lst Sess. 7 (1935).

6. For a more general analysis of the California unemployment insurance program, see Comment, The Claimant Complains: Unemployment Insurance in California, 10 U.S.F. L. REv. 297 (1975) [hereinafter cited as Claimant Complains]. For discussions of the listory and development of unemployment imsurance in the United States, see generally Symposium-Unemployment Insurance, 55 YALE L.J. 1 (1945); Symposium-Unemployment Insurance, 8 VAND. L. REV. 179 (1955).

7. HABER \& MURRAY, supra note 5, at 27.

8. Ch. $531, \$ \$ 301-03,901-10,49$ Stat. 620 (1935) (codified in scattered sectious of 26,42 U.S.C.).

9. HABER \& MuRRAY, supra note 5, at 28-33; Comment, Charity versus Social Insurance in Unemployment Compensation Laws, 73 YALE L.J. 357, 359 (1963) [hereinafter cited as Social In. surance].

10. Indeed, all states, the District of Columbia, and the (then) territories of Alaska and Hawaii close to participate by June 30, 1937. B. StEWART, PlannING AND Administration of UNEMPLOYMENT COMPENSATION IN THE UNITEd STATES 27 (1938).

The Social Security Act established a federal payroll tax on employers, but provided a credit of up to ninety percent for contributions paid under state unemployment compensation laws. I.R.C. $\$ 3302$. The Internal Revenue Code also provides a specific credit as an incentive to employers to stabilize their work forces. This provision, by which the unemployment compensation experience of employers' former employees determimes the employers' respective tax liabilitics, allows employers to credit against their federal tax hability an amount equal to the difference 


\section{ployment compensation.}

The rush toward this new system was motivated not only by economic concerns, but also by a desire to support "the dignity and independence of the unemployed." 11 Hence payments "earned by the claimant and correlated with the duration and wages of his prior en1ployment" were made "a matter of right as opposed to need." 12 The history of unemployment insurance is marked, however, by a concern that an absolute right to unemployment benefits would imduce hard workers to forgo employment and, at least temporarily, live off of their benefits imstead. ${ }^{13}$ Thus the system compensates only involuntary ${ }^{14}$ un-

between their actual state tax liability and their maximum potential state tax liability. I.R.C. $\S 3302$ (b). The Social Security Act requires that state laws meet various federal standards before the Social Security Board could approve them, so that the states' employers could take advantage of the federal tax credits. I.R.C. \&3304(a).

11. Social Insurance, supra note 9, at 359-60. Consider also this statement issued in 1955 by the United States Department of Labor:

Unemployment imsurance is a program . . . for income maintenance during period [sic] of involuntary unemployment due to lack of work, which provides partial compensation for wage loss as a matter of right, with dignity and dispatch, to eligible individuals. It helps to prevent the dispersal of the employers' trained work force, the sacrifice of skills, and the breakdown of labor standards during temporary unemployment.

Bureau of Employinent Security, U.S. Dep't of Labor, Major Objectives of Federal Policy with Respect to the Federal-State Employment Security Program, (General Administration Letter No. 305, April 25, 1955), quoted in HABER \& MURRAY, supra note 5, at 26. The notions of dignity inherent in the systen have been terned "the ethical import of uneinployment compensation." Social Insurance, supra note 9, at 360. As Haber and Murray observe, the program "not only prevents destitution, but enables [clainants] to maintain their self respect." HABER \& MURRAY, supra note 5, at 29.

This focus on dignity and payment as a matter of right does not, of course, bar legislatures from using the vehicle of a social insurance program to accomplish other social goals such as stabilization of employınent. See, e.g., id. at 26; Packard, Unemployment without Fault; Disqualifcations for Unemployment Benefits, 17 VILL. L. REv. 635, $636 \mathrm{n} .7$ (1972). It does, however, conteinplate overriding principles that must be the guiding force when shaping eligibility provisions for such programs.

12. Social Insurance, supra note 9, at 361-62 (footnotes oinitted). See, e.g., Burns, Unemployment Compensation and Socio-economic Objectives, 55 YALE L.J. 1, 2-3 (1945).

"[P]ayments as a matter of right" expresses the intention that unemployment compensation foster and make secure the independence (actual and felt) of the individual, his dignity and autonomy, and his sense of economic security. The ethical relation between society and the clainiant is that of obligee and obligor, not benefactor and beggar.

Social Insurance, supra note 9, at 362 (footnotes omitted).

13. See, e.g., Cal. State Unemp. Comm'n, Report and Recommendations 739-45 (1932); Unemployment Insurance: Hearings on H.R. 7659 before a Subcomm. of the House Comm. on Ways and Means, 73d Coug., 2d Sess. 24 (1934) (question of Rep. John W. Bochne, expressing feat that "unemployment insurance will eventually lead to a large number of American citizens being perınanent objects of charity."); id. at 28-29 (statement of Sen. Robert F. Wagner); id. at 3940 (statement of Abraham Epstein).

Some disincentive effects may indeed occur. See generally R. MUNTS \& I. GARFINKEL, THE WoRK Disincentive EFFECTS OF UNEMPLOYMENT INSURANCE (Upjohn Inst. Studies in Unemp. Ins. No. 13, 1974).

14. Consider the Cahifornia legislature's declaration of policy regarding that state's unemployinent insurance program:

[T] he public good and the general welfare of the citizens of the State require the enactinent of this measure . . . for the compulsory setting aside of funds to be used for a 
employment and seeks the facilitation of rapid reentry into the active labor force.

But distinguishing those claimants who are involuntarily unemployed froun those who "choose" not to work is a difficult chore, fraught with subjective judginents. California has adopted a number of tests to deternime eligibility and to ensure that benefits are paid only to claimants who fall within the defined risks covered by the program. While there are strong pressures in the system for strict administration of the tests, ${ }^{15}$ it is important that a dehcate balance be struck between the values that lay behind enactinent of the prograin and the ever-present concern that compensation of idleness will lead to massive abuse of the program providing the compensation. ${ }^{16}$ This balance should be kept in mind while considering the various tests of eligibility discussed throughout this Cominent.

\section{B. Eligibility Requirements}

Ehigibility for unemployment compensation benefits generally requires both past and present "attachment"17 to the work force: (1) a minimum amount of past employment; (2) a loss of that employment

system of unemployment insurance providing benefits for persons unemployed through no fault of their own, and to reduce involuntary unemployment and the suffering caused thereby to a minimum.

Cal. Unemp. INS. Code $\$ 100$ (West 1972).

15. The structure of the law contributes to this aspect of the program. California law provides for compulsory employer contributions to an unemployment compensation fund, id. § 976, and, because of the experience rating provision, see note 10 supra, employers take a great interest in the award of benefits to former employees; their respective tax liabilities liang in the balance. See, e.g., Packard, supra note 11, at 635 n.3; Social Insurance, supra note 9, at 368.

The employer is not the only party interested in the ease with whicli potential claimants may establish their eligibility for benefits. The department and the Cahfornia Unemployment Insurance Appeals Board have a duty to protect the integrity of the fund; they must serve two roles: ensuring that claimants receive benefits to which they are entitled under the law, and preventing claimants who are not so entitled from also collectmg benefits. While these roles need not necessarily clash, in practice difficulties arise.

[C]ourts and administrative agencies sometimes invent doctrimes, presumptions and rules whicl ignore or exceed the legislative intent. The necessity for such inventiveness flows from the practical difficulty of processing and deciding numerous claims promptly, and from the dual role of the various administrative agencies to assist the unemployed in a time of need, yet to protect a limited fund from ineligible claimants so that an employer's reserve accoumt is not unfairly cliarged.

Packard, supra note 11, at 653-54. See Claimant Complains, supra note 6, at 306-08 (arguing that the administrative duty to protect the fund leads to an anticlaimant bias in administrative interpretations of facially neutral legislative provisions).

16. See HABER \& MURRAY, supra note 5, at 265.

17. "Attachment" is a term of art in unemployment imsurance law, and refers to the relationship between a given claimant and the labor force. It may be used to describe either the previous employment status (past attachment) or the current employment status (present or current attachment) of an individual. "Current attachment" is not synonymous with "currently employed," but rather refers to the desires, efforts, ability, and likelihood of the individual gaining employment in the reasonably near future. 
through no fault of the applicant; and (3) present availability for, and an active search for, suitable work.

\section{Past Attachment}

The administration of California's unemployment compensation system is bottomed on a requirement of "past attachment"18 of the claimant to the labor force. ${ }^{19}$ The program, funded by taxcs paid by both employees and employers, presupposes that funds for benefits will be generated from busmesses employing the insured workers. Like a private insurer, the system attempts to allocate the tax burden by requiring a higher payment by employers whose past record manifests a higher risk of unemployment. ${ }^{20}$ This allocation, and the requirement of past attachment by the claimant, attempt to assure that payouts are made to persons for whom the system has generated the insurance funds, so that the rate of payouts and the base of support will remain roughly in balance. ${ }^{21}$

So far, every state has chosen to require some past attachment to the labor force, ${ }^{22}$ but "tests" of this attachment, commonly called "qualifying requirements," 23 vary widely from state to state. Some states require a particular number of weeks of einployment, some a specified level of earnings, and some require both. ${ }^{24}$ California merely

18. The requirement of past attachment narrows the coverage of unemployment insurance somewhat by excluding new entrants as well as individuals who are only margimally part of the work force. The difficulties involved in determining whether or not a new entrant is truly in the job market and the potential drain on the fund from such fringe members of the labor force justify the decision to limit the insured risk to those persons who have already demonstrated, in some forn or another, attachment to the labor force. See HABER \& MURRAY, supra note 5, at 250-51. Additionally, those who can demonstrate previous labor force involvement will in many cases have made contributions to the fund. See Cal. UNEMP. INs. CODE $\$ 984$ (1978 Cal. Legis. Serv. 1166).

19. The labor market to which the concept of "labor force attachment" apphes is not measured in terms of the existence of job vacancies since unemployment insurance is designed to coinpensate for the lack of such vacancies. Rather, a labor market exists for an individual when "the type of services which an individual is offering is generally performed in the geographical area in which he is offering them." Freeman, supra note 4, at 124. See R. AltMan, supra note 4, at 110 .

20. See note 10 supra.

21. See Haber \& MurRay, supra note 5, at 341-42. Stabilization of employment was another objective of the system. Id. at 337-38. It is doubtful whether experience rating has had any such effect. Id. at 340-41. The objective of increasing employer interest and participation was also of some importance. Id. at 344-46. See generally Amold, Experience Rating, 55 YALE L.J. 218 (1945); Temple \& Nowacek, Experience Rating: Its Objectives, Problems and Economic Implications, 8 VAND. L. REv. 376 (1955).

22. CSUIL, supra note $4, \S 310$, at 3-3.

23. Id; HABER \& MURRAY, supra note 5, at 113.

24. CSUIL, supra note 4, \& 310, at 3-3, Table 301, at 3-27 to 3-29. See Haber \& MurRay, supra note 5 , at $112,250-55$. 
requires earnings of at least $\$ 750$ in the claimant's "base period."2s

\section{Cause of Unemployment}

Consistent with its declaration that coinpensation shall be paid only for involuntary unemployment, Cahfornia, as well as every other state, disqualifies claimants from receipt of benefits if they are found to have "voluntarily" quit their most recent job without "good cause,"26 or if they were discharged for misconduct. ${ }^{27}$ Moreover, claimants who are out of a job because of a labor dispute or because they have become disabled are also denied benefits in most states, including California. ${ }^{28}$

\section{Present Attachment}

The claimant's unemployment must remain involuntary, as well as commence that way. Every state has thus inserted a variety of provisions in their unemployment compensation laws to test current labor force attachment; the system assumes that "it is necessary to continue to test whether [a claimant] is still im the labor market and genuinely unemployed." 29

There are four elements to the California requirement of present attachment: claimants must (a) accept any offer of suitable work unless they have good cause for refusing; ${ }^{30}(\mathrm{~b})$ make reasonable efforts to seek suitable work on their own behalf; ;1 (c) be able to do suitable work; ${ }^{32}$ and (d) be available for suitable work. ${ }^{33}$ The premise underlying these

25. CAL. UNEMP. INS. CODE $\S 1281$ (West 1972). Section 1275 provides for determination of the relevant base period by which qualification for benefits may be established. Id. $\S 1275$.

26. CSUIL, supra note 4, § 430, at 4-5, Table 401, at 4-27 to 30. See, e.g., Cal. Unemp. 1ns. CODE $\S 1256$ (West 1972). Note that for the purposes of the program those who voluntarily quit their jobs will be defined, at least temporarily, as voluntarily unemployed; an employee's unsuccessful attempt to locate replacement employment, even with his former employer, does not alter this status.

27. CSUIL, supra note $4, \S 435$, at 4-7, Table 402, at 4-31 to 34. See, e.g., CAL. UNEMP. INs. CODE $\S 1256$ (West 1972).

28. CSUIL, supra note $4, \S 445$, at 4-10 to 4-12, Table 405 , at 4-41 to 4-43 (labor disputes), $\S 405$, at $4-1$, Table 400 , at 4-23 to 4-25 (abihity to work).

29. Haber \& MurRay, supra note 5, at 249. See id. at 265 (quoting Bureau of EMployMENt SeCuRity, U.S. Dep't OF LABOR, UNemployment InSURANCE Legislative Policy, ReCOMMENDATIONS FOR STATE Legislation 1962, at 44 (1962)) for the proposition that, "[t]he qualifying requirement and the requirement that claimants be able and available for work are the two halves of a single requirement that protection be limited to unemployed members of the labor force."); R. Altman, supra note 4, at 2; Coumment, supra note 4, at 736.

In light of claimants' demonstrated interest in employinent, states could presume that the generally limited amount (see generally HABER \& MURRAY, supra note 5, at 173-198) and duration (see generally id, at 199-248) of benefits would provide sufficient inducement for individuals to seek further employment on their own, such that any continumg unemployment may be assumed to be involuntary. They have, however, not done so.

30. CAl. Unemp. Ins. Code $\S 1257$ (West 1972).

31. Id. $\S \S 100,1253(\mathrm{e})$.

32. $I d . \$ 1253(\mathrm{c})$.

33. Id. Although the able and available requirements are often discussed in the literature as 
requirements ${ }^{34}$ is that individuals who are truly attached to the labor force and who are involuntarily unemployed will hold themselves available and will not refuse offers of suitable employment. A related notion is that persons who truly desire to be employed will actively seek employment. Thus, states generally require that claimants register for work with the employment service $e^{35}$ and make active searches for work. ${ }^{36}$ In most states, including California, the statute explicitly requires such a searcl. ${ }^{37}$ Where the statute is not explicit, courts and administrative agencies may find that sucl a requirement is inherent in the more basic provision mandating that claimants remain "able and available for work." 38

\section{a. Refusals of Suitable Work}

The most certain indicator of present attachment is acceptance or refusal of an actual offer of work, smce acceptance of such an offer results in employment. Because the consequences of the response to the offer are real rather than liypotlietical, an offer of suitable employment is tlie preferred inethod of testing labor force attachment. ${ }^{39}$ This is so despite the inclusion of job referrals, ${ }^{40}$ as well as hard offers, withm the definition of "offer," since the exploration of a particular job opportunity is the result in eitlier case. Notwithstanding the true employment potential of botli job offers and referrals, there are a number of complications that prevent the work refusal test from resolving all questions concerning current labor force attachment. First, as both a safeguard for individuals on the program, and as a means of preserving the efficient use of societal resources, claimants are not required to accept all offers of work, but only those that are for suitable work, whicls the claimant does not liave good cause to refuse. ${ }^{41}$ Second, the depart-

if they are a unified whole, they are actually two quite different aspects of the general command that claimants be currently attached to the labor market.

34. All states generally require that their claimants meet these requirements. See generally CSUlL, supra note $4, \S 400$, at 4-1.

35. Id. § 405, at 4-1. See, e.g., Cal. Unemp. Ins. Code $\S 1253$ (b) (West 1972).

36. CSU1L, supra note $4, \S 415$, at 4-3.

37. Cal. UNemp. Ins. Code $\$ 100,1253$ (e) (West 1972).

38. Freeman, Availability: Active Search for Work, 10 OHIo ST. L.J. 181, 183 (1949) [hereinafter cited as Active Search].

39. HABER \& MURRAY, supra note 5, at 424.

40. Cal. Unemp. INS. CODE $\S 1257$ (b) (West 1972) ("An imdividual is . . . disqualified . . . if . . . : (b) He, without good cause, refused to accept suitable employment when offered to him, or failed to apply for suitable employment wlien notified by a public employinent office." (emphasis supplied)); Precedent Benefit Decisions P-B-324 \& P-B-6 (Cal. Unemp. Ins. Appeals Bd.). [The board issues binding rulings called Precedent Decisions. See CAL. UNEmP. INS. CODE § 409 (West Supp. 1978). Those rulings regarding benefit determinations (as opposed to, for example, tax liability) are referred to as Precedent Benefit Decisions and, hereinafter, will be cited simply as P-B-(decision number).]

41. Of course, any refusal of suitable work would raise an availability question, viz. whether the circumstances that led to the refusal prevent acceptance of all (or at least a substantial amount 
ment receives listings for only a sinall proportion of job openings, ${ }^{42}$ so actual testing of current attachment by this test can occur in relatively few cases. Moreover, proposals to force enployers to inake all listings available to the department are resisted by einployers. ${ }^{43}$

There are two components to the refusal of suitable work provision. Unless botli are met, refusals by claimants will not inake them ineligible for benefits. ${ }^{44}$ First, the offered work unust be "suitable," and second, the imdividual must not have "good cause" for refusing it.

Suitability is determined by evaluating a variety of factors that are spelled out in the Unemployment Insurance Code. ${ }^{45}$ Among these are the individual's "prior training, his experience and prior earnings, his length of uneinployment and prospects for securing local work in his customary occupation." 46 Thus, for example, as the length of time a given claimant is uneinployed increases, the department may require the claimant to accept lower wages than would otlerwise be suitable. ${ }^{47}$

The "good cause" component is fairly amorplious; the California Supreme Court has defined good cause to be "an adequate cause, a cause that comports with the purposes of the Unemployment Insurance Code and witl other laws." 48 The question of whether or not an indi-

of) work. Without some other test of labor force attachment, such as availability, a claimant with good cause to refuse all offers of employment would be eligible for benefits, although such a claimant's current attachment would be, to say the least, suspect.

42. See Haber \& MURRAY, supra note 5, at 419, 434-35.

43. See id. at 427-29, 434-35. also.

44. As observed in note 41 supra, a refusal of suitable work will raise an availability issue

45. See Cal. Unemp. Ins. Code $\S \S 1258,1258.5,1259$ (West Supp. 1978).

46. Id. $\S 1258$.

47. Employment Development Dep't, State of Cal., Benefit Determination Guide, at SW 295-1, AA 5-16 [heremafter referred to as BDG]. The Guide "is a procedural manual prepared by the Department for its internal use." Claimant Complains, supra note 6, at 305. See CaL. Unemp. INS. Code $§ 1258$ (West Supp. 1978).

The requirement that a claimant accept lower wages after a given time coinports with the dual purposes of increasing the speed of reentry into employment without inefficient use of labor and reducing the unemployment rolls as quickly as possible. As the length of time that the individual has been unemployed increases, the likelihood that the individual can find employment in the more remunerative fields decreases; one could say that an individual who restricts acceptable employment in such circumstances is no longer substantially attached to the labor market.

48. Syrek v. Unemployment Ins. Appeals Bd., 54 Cal. 2d 519, 529, 354 P.2d 625, 630-31, 7 Cal. Rptr. 97, $102-03$ (1960) (good cause for refusal to sign loyalty oath); see Prescod v. Unemployment lns. Appeals Bd., 57 Cal. App. 3d 29, 127 Cal. Rptr. 540 (1st Dist. 1976). Good cause has also been described as connoting " 'real circunstances, substantial reasons, objective conditions, [and] palpable forces that operate to produce correlative results." California Portland Ccment Co. v. Unemployinent Ins. Appeals Bd., 178 Cal. App. 2d 263, 272-73, 3 Cal. Rptr. 37, 43 (2d Dist. 1960) (quoting Bliley Elec. Co. v. Unemployment Comp. Bd. of Review, $158 \mathrm{~Pa}$. Super. 548, 556, 45 A.2d 898, 903 (1946)).

Some states have restricted good cause to causes that are "'attributable to the employer.' California has not doue so." California Portland Cement Co. v. Unemployment Ins. Appeals Bd, 178 Cal. App. 2d 263, 271-72, 3 Cal. Rptr. 37, 42 (2d Dist. 1960). See Sanchez v. Unemployment Ins. Appeals Bd., 20 Cal. 3d 55, 569 P.2d 740, 141 Cal. Rptr. 146 (1977); CSUIL, supra note 4, \& 
vidual has good cause to refuse employment, to voluntarily quit employment, or to restrict availability involves consideration and reevaluation of personal reasons behind the claimant's action. ${ }^{49}$

\section{b. Efforts to Seek Work}

Because the unemployment compensation prograin emphasizes reentry of unemployed individuals into the labor market, ${ }^{50}$ "seek-work" provisions become an almost inherent aspect of any test of current labor force attachinent. ${ }^{51}$ If claimants are to be, and desire to be, reemployed, it is generally thought that they must, and naturally will, "make all reasonable effort to secure einployment on their own behalf." 52

The statute directs that the department require claimants "[to conduct searches] for suitable work in accordance with specific and reasonable instructions of a public employment office."53 The relevant Employment Development Department regulation ${ }^{54}$ specifies a nuinber of actions that "will be considered reasonable efforts to seek work . . . if found by the department to constitute effective ineans of seeking

430, at 4-6 Table 401, at 4-27 to 4-28, 4-28 nn.1 \& 2. See generally Simrell, Employer Fault vs. General Welfare as the Basis of Unemployment Compensation, 55 YALE L.J. 181 (1945).

49. See, e.g., Sanchez v. Unemployment Ins. Appeals Bd., 20 Cal. 3d 55, 69-70, 569 P.2d 740, 749-50, $141 \mathrm{Cal}$. Rptr. 146, 155-56 (1977). In the case of work refusals or voluntary resignations (often referred to as "voluntary quits"), it is both statutorily required and sound pohicy to inquire into the reasons for a claimant's actions. In such cases the claimant's actions have actually prevented or terminated employment. Thus, to determine whether or not the claimant is involuntarily unemployed requires inquiry into the circumstances behind the action. See JoINT INTERIM LEgis. UNEMP. INS. COMM., CAL. Legislature, Report 5 (1969) [heremafter cited as JolNT INTERIM COMM. REPORT] (recommending that the Code be amended to require the department to determime that claimants who, with good cause, refuse offers of suitable work, are "able and available"). The BDG currently provides for a determmation under these circumstances. BDG, supra note 46, at AA 5-12. If the claimant who has quit or refused a job offer has not been the victim of some compelling circumstances, the claimant's action is by choice-i.e, voluntary-and not within the protected risks of the program.

50. See HABER \& MURRAY, supra note 5, at 26, 418-37; Active Search, supra note 38, at 181. See also I.R.C. $\$ 3304(a)(1)$.

51. Active Scarch, supra note 37, at 188; Williams, Eligibility for Benefits, 8 VAND. L. REv. 286, 291 (1955). But see London v. Board of Review of Emp. Sec., 244 S.E.2d 331, 335-38 (W. Va. 1978) (refusing to establish "a blanket requirement that all who seek benefits . . . must be personally job-hunting," when the state legislature had not done so, 244 S.E.2d at 335).

52. See CAL. UNEMP. INS. CoDE $\$ 100$ (West 1972) (requiring that such an effort be made). The desirability of individual efforts to seek employment does not necessarily dictate that claimants ought to be forced to umdertake them under threats of benefit denials. See London v. Board of Review of Dep't of Emp. Sec., 244 S.E.2d 331, 336 (W. Va. 1978). Claimants could be trusted to make such searches on their own. Incentives could be employed as an alternative, as could a variety of devices to force or induce employers to provide job listings with the employment service, see HABER \& MURRAY, supra note 5, at 434-35, so as to enable the department both to facilitate reemployment and to test current labor force attachment with hard job offers. Indeed, these goals have been dubbed as the two legitimate purposes of the seek-work requirement itself. Active Search, supra note 38 , at 183 . These methods could, of course, be employed in conjunction with forced as well as voluntary work searches.

53. CAL. UNEMP. INS. Code $\S 1253$ (West 1972); see also id $\S 100$.

54. 22 CaL. AD. Code $\$ 1253(\mathrm{c})-1$ (1974). 
work by the particular claimant." 55 In all events, "[t]he claimant shall be required to [follow] a course of action which is reasonably designed to result in his prompt reemployment in suitable work." 56

\section{c. Able to Work}

All states, including California, insist on another part of the current attachment requirement-that claimants have the physical and inental ability to reenter the work force. ${ }^{57}$ Individuals without this capacity are not within the risk pool with which unemployment compensation is concerned; claimants cannot be attached if they cannot work. Such individuals are thought to be adequately protected by workers' compensation, ${ }^{58}$ disability insurance, ${ }^{59}$ and the various forms of federal and state welfare rehef.

Claimants need not, however, be capable of performing the same type of work as they performed in the past. "[T]he general priniciple should be that an individual is able to work, despite his age and physical condition, if there is a market in the geographical area in which he is willing to work for services which he is able to perform." 60

\section{d. Availability for Work}

Claimants inust not only be able to work, they must also be "available" for work. ${ }^{61}$ The broad concept of availability has three independent attributes: willingness, ability, and readiness to accept

55. Id. The actions endorsed by the department include, among others, applying for work directly with employers, including the claimant's former employers, responding to "want ads," and registering with a variety of placement services or facilities.

56. Id. See, e.g., P-B-196. The question of how broad and vigorous a search must be before it is deemed "rcasonable" should be viewed as a corollary to the major question addressed in Part II of how much availability is sufficient. The department has developed three "seek-work plans" that set reasonableness standards to accommodate the needs of claimants in different circumstances. Seek-Work Plan "A" gcnerally requires claimants to make a broad search covering a variety of potential employment sources. See text accoinpanying and notes 54-55 supra. Plan "B" requires a claimant whose union is responsible for hirmg simply to "[r]egister with your Union and ineet all Union requirements that pertain to or inay affect your being dispatched to a job." (Plans " $A$ " and " $B$ " can be found in EMPloyment Dev. Dep't, STATE OF CAL., UNEMPLoyment INSURANCE HANDBOOK FOR ClAIMANTS [at inside front cover] (1975).) Finally, Seek-Work Plan "C" (actually, it is just entitled "Seek-Work Plan" by the department, it is designated here as "C" to distmguish it from the 'other two plans) provides that, for claimants in a very limited number of circumstances, such as dcfinite job promise, seasonal layoff, and trade dispute, "reporting to the Department as scheduled is sufficient to ineet this seek-work requirement." Form DE 4681 Rev. 6 (3-74). See also 22 CAL. AD. CODE § 1253(c)-1 (1974).

57. CSUIL, supra note 4, §§ 400-05, at 4-1; Freeman, supra note 4, at 128.

58. See generally HABER \& MURRAY, supra note 5, at 469-71, 502.

59. See CAL. UNEmp. INs. CODE $\$ \S 2601-3272$ (West 1972 \& Supp. 1978). "The purpose of [disability insurance] is to compensate in part for the wage loss sustamed by individuals unemployed because of sickness or imjury and to reduce to a minimum the suffering caused by unemployment resulting therefrom." Id. $\$ 2601$.

60. Freeman, supra note 4, at 129.

61. See, e.g., CAL. UNEMP. INS. CODE $\S 1253$ (c) (West 1972). The precise meaning of this 
"suitable" work. ${ }^{62}$ As discussed, claimants must be able, and, of course, willing to work, but the "crux of the availability problem" is that claimants must be ready to work; ${ }^{63}$ their "personal circumstances" and any self-imposed conditions that restrict employment options must be such that the claimant is still substantially free to accept suitable work. ${ }^{64}$

Whether it is "universal as an mevitable result of a program which compensates for wage loss," 65 or is superfluous ${ }^{66}$ in hight of the work refusal and work search tests, the availability requirement remains the most controversial and important hurdle to an apphicant's receipt of unemployment benefits. In Sanchez $v$. Unemployment Insurance Appeals Board, ${ }^{67}$ the California Supreme Court addressed for the first time the question of the appropriate standard for evaluating an imdividual's "availability" for purposes of the unemployment insurance program.

II

\section{LIMITS OF AVAILABILITY}

\section{A. Sanchez: The Substantial Attachment Test}

As imdicated at the outset of this Comment, the department had

term has been the subject of discussion in the literature ever since unemployment coinpensation programs were euacted in this country in the 1930's. See, e.g., sources cited in note 4 supra.

62. Freeinau, supra note 4, at 124. California has adopted this tripartite approach. See, e.g., P-B-17; P-B-170; BDG, supra note 47, at AA 5-1 to 5-2; Claimant Complains, supra note 6, at 305.

63. Freeman, supra note 4, at 129.

64. Id.

65. R. Altman, supra note 4, at 2.

66. The problem with the idea that the availability requirenent is superfluous is the inadequacy of the other two requirements. Sole rehance on an offer of suitable work to test current attachment may be misplaced even though sucls an offer is the inost objective indicator of such attachment. See notes $41 \& 43$ and accompanying text supra. As observed already, the eunploymeut service receives only a fraction of the potentially available job listings and consequently can test only a small portion of the total claimant pool by such offers. Moreover, if an individual lias good cause to refuse the offer, some alternative measure seems necessary; the question becomes whether the circuinstances responsible for providing the good cause have, in addition, essentially removcd the claimant from the active work force.

The work searcly requirement suffers from similar limitations-individual efforts to seek work do not always fully reveal whether the individual's circumstances actually allow acceptance of employinent. In other words, the scopo of the required search must be defined and evaluated for its sufficiency as reaching a substantial labor market. This gap may be filled by looking at the types and quantity of work which claimants are "willing, able, and ready to accept," viz. their availability.

"Quantity," in this context, lras a double ineaning. It refers both to the amount of work the claimant is willing to do per week, Glick v. Unemployment Ins. Appeals Bd., 76 Cal. App. 3d 450, 142 Cal. Rptr. 840 (3d Dist. 1978) (availability solely for part-time employinent does not satisfy the statute, even though the individual's qualifying earnings were derived froin such employment), hearing granted Mar. 30, 1978 (No. SF 23811), and to the times (days and hours) in tlie week that the person is willing to do the work.

67. 20 Cal. 3d 55, 569 P.2d 740, 141 Cal. Rptr. 146 (1977) (Mosk, J.). 
denied benefits to claimant Sanchez after she indicated that she could not accept einploynent that would require her services on either Saturdays or Sundays; lack of childcare assistance on those days forced her to spend them taking care of her four-year old son. ${ }^{68}$ The department's determination was, in turn, affirmed by a hearing referee, the appeals board, and by the superior court, which refused to issue a writ of mandate compelling the departinent to grant benefits. ${ }^{69}$ These tribunals agreed that, under the availability requireinent, "a claimant "cannot impose restrictions on suitable work, such as limitations on hours, days, shifts or wages, which will materially reduce the possibility of obtaining employinent," "70 as Sanchez had done. ${ }^{11}$

The suprenie court unanimously reversed, in essence declaring that Maria Sanchez was eligibile for benefits because she had "good cause" for making herself "unavailable" on weekends. ${ }^{72}$ The court establislied a two-pronged measure of availability, stating that " availability for work'... requires no more than (1) that an individual claimant be willing to accept suitable work which he has no good cause for refusing and (2) that the claimant thereby inake himself available to a substantial field of einployment."73 This laid the groundwork for a shift im the focus of the availability inquiry froin a search for a less than substantial reduction in attaclument to a search for substantial remaining attacliment. $^{74}$

The first part of the court's bifurcated "test," adopting the good cause exception, is based upon the conclusion that the availability and refusal of suitable work provisions must be read together. ${ }^{75}$ The suitable work requirement allows claimants to refuse actual offers of work if

68. Id. at 59, 569 P.2d at 743, $141 \mathrm{Cal}$. Rptr. at 149. Specifically, she was found "unavailable" under Cal. UNemp. Ins. Code § 1253(c) (West 1972). See note 2 supra.

69. The court of appeal had affirmed the trial court, Sanchez v. Unemployment Ins. Appeals Bd., 131 Cal. Rptr. 354 (2d Dist. 1976), vacated upon grant of California Supreme Court hearing, Oct. 21,1976 , and was not mentioned by the supreme court in its decision.

70. 20 Cal. $3 \mathrm{~d}$ at 60,569 P.2d at 743,141 Cal. Rptr. at 149 (emphasis supplied). Thus Sanchez's availability was measured by the test that the department already generally used to measure availability when claimants had voluntarily imposed restrictions on the jobs that they would accept. The department's policy is that "unreasonable" self-imposed restrictions "may be acceptable depending on the portion of the labor market eliminated." BDG, supra note 46, at AA 5-8 (emplasis in original). The department's standard for testing restrictions that are created by force of circumstances, or that are self-imposed but reasonable, on the other hand, is in terms of "the labor market remaining." Id. (emphasis in original).

71. 20 Cal. $3 \mathrm{~d}$ at 61,569 P.2d at 744, 141 Cal. Rptr. at 150.

72. More precisely, the supreme court ordered the trial court to issue a pereinptory writ of mandate coinpelling the board to set aside its determination that Sancliez was mehigible for benefits. Id. at 72, 569 P.2d at 751, 141 Cal. Rptr. at 157 .

73. 20 Cal. $3 \mathrm{~d}$ at 67,569 P.2d at 748,141 Cal. Rptr. at 154 (footnotes omitted) (emphasis supplied).

74. In some cases, less than substantial attachment may be acceptable. See id. at 67 n.11, 569 P.2d at 748 n.11, 141 Cal. Rptr. at 154 n.11.

75. 20 Cal. 3d at $62-64,569$ P.2d at 745-46, 141 Cal. Rptr. at 151-52. The court of appeal had 
they have good cause for doing so. The failure to apply that same standard when the "refusal" is made in advance under the availability provision, would, as the court realized, render "nugatory" the suitable work provision. ${ }^{76}$

The second half of the Sanchez test, requiring availability for a "substantial field of employment," follows from the court's behef that the availability requirement refers not only to the circumstances of the individual, but also "to the functions and needs of the economy"; a claimant must be "[accessible] to work for which there is some social demand." "77 Hence, claimants must be "available for work for which there is a substantial field of potential employers."

Although the Sanchez test was announced as if it were new, it is clear that it has substantial underpinnings $m$ prior court and board decisions, as well as departmental procedure. ${ }^{79}$ As the court noted, the relevance of a good cause determination to the availability requirement

taken this general approach to the statutory framework much earlier, as the court appeared to recognize. Id. at $64,569 \mathrm{P} .2 \mathrm{~d}$ at $746,141 \mathrm{Cal}$. Rptr. at 52 . See notes $79-80$ infra.

76. Id. at 63, 569 P.2d at 745, 141 Cal. Rptr. at 151 (quoting Freeman, supra note 4, at 125).

77. Id at 65,569 P.2d at 746, 141 Cal. Rptr. at 152 (citations omitted). The court thus accepted the view that the purpose of the availability requirement is to assure "that a claimant is 'attached to the labor market." "Id.

78. Id., 569 P.2d at 747, 141 Cal. Rptr. at 153.

79. The test could be found not only in Garcia v. California Emp. Stab. Comm'n, 71 Cal. App. 2d 107, 161 P.2d 972 (3d Dist. 1945), and the BDG, supra note 47, see note 70 supra, but as the court in Sanchez itself observed, support for the rule could be garnered in a number of the board's own precedent benefit decisions, 20 Cal. $3 \mathrm{~d}$ at $64 \mathrm{n} .10,65-66,569 \mathrm{P} .2 \mathrm{~d}$ at $746 \mathrm{n} .10,747$, 141 Cal. Rptr. at 152 n.10, 153. See P-B-198. In defense of the court, one should note that it was faced with an opinion of the court of appeal that demonstrated a total misunderstanding of the interrelationship of the availability and work refusal provisions, not to mention Garcia. See Sanchez v. Unemployment Ins. Appeals Bd., 131 Cal. Rptr. 354, 366 (Cal. App., 2d Dist. 1976) ("[s]ection 1253 ... does not contain any exception based on 'good cause' "), vacated upon grant of California Supreme Court hearing, Oct. 21, 1976. Thus, despite the estabhished nature of the test laid out by the court, some clarification may have been in order.

Aside from this need to explain the law, the court's opinion could be read as simply finding that the lower tribunals in this case had failed to find good cause where it did indeed exist; although the court remanded the case for a determination of whether or not Sanchez did have good cause and was substantially attached to a labor market, $20 \mathrm{Cal}$. 3d at 72, $569 \mathrm{P} .2 \mathrm{~d}$ at $751,141 \mathrm{Cal}$. Rptr. at 157, the court essentially directed the lower courts and board to find that she did.

"[F]or the guidance of the board in [Sanchez] and future cases," id. at 69,569 P.2d at 749, $141 \mathrm{Cal}$. Rptr. at 155 , the court thoroughly considered both the question of parental responsibilities as providimg good cause for availability restrictions and the respective (board and claimant) burdens of proof regarding labor force exposure. In this respect, Sanchez may be important. Essentially, the court declared that "a claimant who is parent or guardian of a minor has 'good cause' for refusing employment which conflicts with parental activities reasonably necessary for the care or education of the minor if there exist no reasonable alternative means of discharging those responsibilities." Id. at 70,569 P.2d at 750, 141 Cal. Rptr. at 156. Further, the burden lies with the department to establish the unavailability ("to a substantial field of employment") of claimants who can demonstrate that they are "available for suitable work which [they have] no good cause for refusing." Id. at 71, 569 P.2d at 751, 141 Cal. Rptr. at 157. Claimants had traditionally carried the full burden of demonstrating their availability. Id. at 70,569 P.2d at 750,141 Cal. Rptr. at 156, and cases cited therein. 
was established long ago in Garcia v. California Employment Stabilization Commission. ${ }^{80}$ Thus, the intriguing feature of Sanchez is not so much the test of availability that it lays out, ${ }^{81}$ but rather the question

80. 71 Cal. App. 2d 107, 161 P.2d 972 (3d Dist. 1945). In Garcia, the department disqualified a claimant who refused a referral because of a lack of transportation. The appeals board found that the claimant had good cause for the refusal (and hence was not disqualified under the refusal of suitable work provision), but nevertheless denied benefits on the ground that the claimant was unavailable. The court of appeal reversed the board, stating that, as the refusal of the work referral was for good cause, so was the unavailability. Therefore the claimant was not necessarily unavailable. Id. at $113,161 \mathrm{P} .2 \mathrm{~d}$ at 975 . This analysis thus limited the scope of the availability requirement to that of the work refusal provision.

The court observed that many claimants shared Garcia's problem, in that "no work existed in their own communities, and because of the lack of transportation facitities they had no means of obtaining employment in the larger labor narkets." Id. at 109, 161 P.2d at 973. Stating that a remedial statute such as the Unemployment Insurance Act "must be liberally construed," the court declared that, "if the unavailability for work be involuntary and without fault, a claimant may not be deprived of benefits." Id. at 113,161 P.2d at 975 . This ostensibly unequivocal statement was tempered by a remand to determine if Garcia was exposed to at least soine work opportunities.

81. In laying out that test, the court failed to consider two possible arguments against its adoption. The court followed Garcia and rejected the reasoning of two Cahfornia Attorney General Opinions, 10 CAL. OP. ATT'Y GeN. 208 (1947) and 24 CAL. OP. ATT'Y GeN. 81 (1954), without any analysis of a relevant statutory amendment with which the latter were concerned. The attorney general, responded to a 1945 amendment to the Act (1945 Cal. Stats. 1110, ch. 572), requiring claimants to be "available for work for such wcek" (the statute now reads "for that week") rather than merely being "available for work." This amendment may have itself been a response to an earlier attorney general opinion, 3 CAL. OP. ATT'Y GEN. 380 (1944), suggesting that "a claimant who has not been called for work during a particular week and who was for a portion of the week able and available for work should be regarded as able and available for work during the entire week." Id at 381 . The later attorney general opimions concluded that the earlier ruling was rendered "obsolete" by the 1945 statutory amendment, and that availability throughout the week was required. 10 CAL. OP. ATT'Y GEN. 208, 211 (1947). In 1954, the attorney general went so far as to say that the "legislature, apparently with deliberation," had omitted a "good cause" excuse from the requirement. 24 CAL. OP. ATT'Y GEN. 81,82 (1954). Neither of the later opinions noted, much less considered the implications of Garcia, decided in October 1945, shortly after the statutory amendment, but not mentioning it, perhaps because the case was based on 1944 facts. Thus, it is unclear whether the Garcia court's contrary reading of the statute was undercut by subsequent developments, or whether the attorney general's opinions were simply incorrect.

In addition to avoiding the history of the attorney general opmions, the Sanchez court also failed to consider the possible negative implications suggested by the statutory listing of numerous specific situations (e.g., death im the immediate family, unlawful or lawful detention, or jury duty, CAL. UNEMP. INS. CODE $\$ \S 1253.1-.8$ (West 1972 and Supp. 1978)), which do not preclude eligibility, although the claimant might otherwise be technically unavailable. It could be argued that such an explicit cataloguing evidences a legislative intent that those be the only exceptions. See Sanchez v. Uneinployment Ins. Appeals Bd., 131 Cal. Rptr. 354, 357 (Cal. App., 2d Dist. 1976), vacated upon grant of California Supreme Court hearing, Oct. 21, 1976.

Although the opinion nuay be a hittle weaker for these shortcomings, they are far from fatal to its logic. The amendment with which the attorney general was concerned, absent other indications of legislative intent to the contrary, seems merely to require that the focus of availability be on the week in question. And, of course, the specificity of the "good cause" type of excuses does not necessarily imply the negative pregnant; the excuses are just as, if not more, likely to be statutory declarations of presumptive good cause in situations of particular concern to the legislature, leaving all others to the discretion of the department. This is especially so in light of the strong reasons that support the court's finding that, at a minimum, good cause may allow claimants in somewhat restricted labor markets to demonstrate that they are in fact available for work. 
that the court expressly left open: must claimants always justify material reductions in availability by showing good cause even though they are still substantially available or "attached" to the labor market? ${ }^{82}$

\section{B. Must There Be Good Cause for a Material Reduction in Attachment?}

\section{Is the "Good Cause" Standard Necessary?}

As the law now stands, individuals who demonstrate substantial current labor force attachment may nonetheless be found ineligible for benefits if their reduction from maximum to substantial attachment was without good cause. ${ }^{83}$ Under the current administration of the good cause requirement, claimants must subject their reasons for restricting their search or availability to departmental scrutiny; if the department does not find good cause for the limitation, the claimant loses benefits.

Yet, the purported basis for coinpelling individuals to demonstrate good cause at all is analytically unsound. The primary justification for requiring that a claimant show good cause for any material reduction in exposure to the labor market is that any increase in availabihty will increase the probability of reemployment, which, in turn, is a prinary goal of the prograin. Yet in the typical case, the impact on reemployinent will be minimal and probably indeterminate, ${ }^{84}$ while the intru-

82. 20 Cal. 3 d at $67 \mathrm{n} .11,569$ P.2d at $748 \mathrm{n} .11,141$ Cal. Rptr. at $154 \mathrm{n} .11$. The answer to this question is of some importance. In 1974 the department made 292,369 "able and available" determinations regarding claimants, and, of these, $49.3 \%$ or 144,197 resulted in "claimants" (there is no indication as to how many of these determinations were multiple, viz. affecting the same claimant nore than one time) being denied benefits, at least temporarily. EMPLOYMENT DATA \& RESEARCh Div., Employment Development Dep't, State of Cal., Report No. 525 (Annual, 1974) [Report No. 525 is a one-page report on nonmonetary determinations issued monthly and annually; it will hereinafter be cited as REPORT No. 525 (date)]. The figures for 1975 and 1976 are for the most part comparable. See RePORT No. 525 (Annual, 1975); REPORT No. 525 (Annual, 1976). In each of these three years, availability determinations exceeded all others, and, except for 1976, also accounted for the greatest number of disqualifications. REPORT No. 525 (Annual, 1976); Report No. 525 (Annual, 1975); Report No. 525 (Annual, 1974). See also Haber \& MURRAY, supra note 5 , at 265.

Identifying the frequency of denials due to self-imposed restrictions is difficult. One study of a fairly small sanple of claimants found that, of those denied benefits for nonavailability, eighteen percent were determined to be ineligible "because their efforts to seek work were unsatisfactory or they had demonstrated in some fashion that they were not willing to work." JoINT INTERIM COMM. REPORT, supra note 49, at 32. It is impossible to determine how many of these individuals were punished for merely "materially reducing" their job opportunities, and how many were denied benefits because they had actually failed to demonstrate substantial labor force attachment.

83. As the board recently observed, "no authorities can be found which hold that less than a readimess, willingness, and ability to accept suitable employment which there is no good cause to refuse will suffice to meet the availabihty requirement." P-B-198, at 4 . This decision was first issued in 1947, but pursuant to the authority vested in the board, CAL. UNEMP. INS. CODE $\S 409$ (West 1972), it was elevated to precedent benefit decision status by the board in 1976 .

84. Reemployment chances will decrease to the extent claimants do not seek jobs in areas 
sion on the individual and the opportunities for the exercise of bureaucratic discretion will be substantial. ${ }^{85}$

Take, for exainple, a hypothetical person, Claudia Smith, who has worked in the past both as an assembly line worker and as a carpenter. Assume that both jobs are suitable work for her now. Out of work at this time, she has decided that she is tired of working on assembly lines-that it is a dead-end job. She is willing to take an assembly line job as a last resort, but is unwilling to spend time searching for one now-preferring, instead, to search for carpentry jobs only.

Pursuant to current law and procedures, the department will ask Claudia if she will search for and accept an assembly line position. If ler answer is no, she will be ineligible even though the inquiry is purely hypotlietical (i.e., the departinent has no such jobs to which it could refer her at this time) and even though she remains substantially attached to the labor market and may have a good chance of obtaining einployinent in her chosen field of carpentry.

The current policy of the department is that it will not perform "the futile act" of making a specific referral or offer of employment if it does not meet the claimant's own conditions. ${ }^{86}$ This, of course, assumes that a claimant's response to a real job offer will be identical to the saine claimant's response to the hypothetical question. It may "not [be] necessary for the departinent to inake applicants content with proffered einployinent," appear content with hypothetical offers of einployment. ${ }^{88}$

The departinent's "liypothetical question"89 gives a claimant in

which might generate offers. They will increase to the extent claimants will concentrate thcir efforts and try harder to obtain employment.

85. It is not difficult to imagine how the eligibility tests, and particularly their administration, could seriously infringe on the privacy, dignity, and autonomy of the individual claimant. For example:

[the availability and suitable work refusal provisions subject] the claimant to the judgment of administrators as to what work is "suitable" for him and how lie must behave to be considered "available," inhibiting the independence and autonomy with which he may choose his vocation and order his affairs. The [requirements are] analogous to the conditions charitable benefactors place upon their bounty-conditions which the social imsurance principle of payinents as a matter of right was supposed to eliminate.

Social Insurance, supra note 9, at 378 (footnotes ounitted).

86. BDG, supra note 46, at AA 160.05-1 (1977).

87. Syrek v. Unemployment Ins. Appeals Bd., 54 Cal. 2d 519, 531, 354 P.2d 625, 632, $7 \mathrm{Cal}$ Rptr. 97, 104 (1960).

88. One of the early and prolific writers on the subject, arguing for a good cause excuse for reductions in availability, stated:

[t]o impose on claimant the burden of deciding in vacuo whether he would be willing to accept any number of different kinds of work under varying circumstances at the peril of losing his benefits would be to exact an impossible condition of eligibility and would tend to substitute for objective standards the purely subjective reactions of the deputy or referee.

Freeman, supra note 4, at 126.

89. It should be noted that liypothetical questions regarding ability may be defensible, while 
Claudia Smith's position an incentive to lie in order to obtam benefits, telling the department her search is unrestricted when she actually restricts lier work search to her cliosen field. Moreover, the department's policy ignores the very real possibility that the origimally negative answer to the question may become positive were an actual offer to be made, especially considering the potentiality of an eight week disqualification for refusing a work referral..$^{90}$ The point is, simply, that an affirmative answer to the hypothetical question probably does not actually increase the odds of reemployment. Inquiry should be directed to where the claimants will searcl and accept work, ratler than where they believe in the abstract they will not. ${ }^{91}$ The determinarive element ought to be whether the claimant's chosen field or fields are substantial enough to make the odds of reemployment reasonably good.

In short, the present systein only encourages game-playing by the department and claimants. Persons who are willing to accept and actively seek work in a substantial field of employinent are forced to prevaricate in response to an unnecessary question about a hypothetical future development that is best handled by other criteria, such as the objective work refusal test. ${ }^{92}$ Furthernore, claimants may more diligently search for employment if they feel that the choice of what to search for and accept is their own.

Assuming that the claimant can satisfy the seek-work test in a cho-

the same questions regarding availability are not. While claimants could be denied benefits on the basis of a question with respect to their ability to perform a hypothetical job, a crucial difference exists between this type of hypothetical question and those based upon claimants' self-imposed restrictions. There is nothing that "unable" claimants can do to change their circumstances-their physical or mental capacity is beyond their control. The importance of this distinction can be seen by viewing the eligibility and disqualification provisions in terms of their function in a social insurance system: producing the proper risk pool.

Some states have taken precisely the opposite position from that suggested here, allowing benefits to those "unable claimants" who do not refuse offers of work, "which is suitable but for [their] disability. . . ." CSUIL, supra note 4, $\S 405$, at $4-1$. This phenomenon seems explainable only in terms of perceived differeuces in the fault of the two classes of claimants.

90. It may be argued that since claimants who would attempt to restrict their availability will immediately modify their plans (i.e., lift restrictions) when they are threatened with a benefit denial, the department might as well pose the question. But if such claimants modify their restrictions in this maimer anyway, it is again difficult to see why substantially attached claimants ought to be forced to demonstrate more; the administration of the availability requirement becomes a charade that rewards the wary or shrewd claimant at the expense of others.

91. Those individuals, who, on the basis of their responses to hypothetical questions, would be classified as unattached to the labor force, may or may not be actually attached. See Chambers v. Unemployment Ins. Appeals Bd., 33 Cal. App. 3d 923, 109 Cal. Rptr. 413 (1st Dist. 1973); Spangler v. Uneinployment Ins. Appeals Bd., 14 Cal. App. 3d 284, 92 Cal. Rptr. 266 (1st Dist. 1971); P-B-260. But see UAW v. California Dep't of Huinan Resources Dev., 58 Cal. App. 3d 924, 130 Cal. Rptr. 368 (1976).

92. At the same time, employers may choose employees from any source at their own leisure; certainly they are not required to take departmental referrals. The program puts undue emphasis on protection of employers from so-called faulty employees, while paying hittle attention to employer efforts to hire claimants. See generally HABER \& MURRAY, supra note 5, at 418-37. 
sen substantial field of employment, there seems to be no reason to demand more under the availability requirement. ${ }^{93}$ Subjective judginents regarding a claimant's "good cause" for restricting availability ought not be made.

This Comment echoes an idea suggested almost thirty years ago. A commentator observed then that denying benefits to claimants solely because they limited acceptable enployment to only one of a number of suitable occupations was to engage im "mere meddling with the claimant's right to choose and change employment." $94 \mathrm{He}$ decried the position of some states that claimants must be available for all suitable work. California has long disagreed with that extreme view, instead requiring, as Sanchez inade clear, that claimants not substantially reduce their availability without good cause for doing so. Thus the current administration of the prograin in California takes a iniddle ground, but the fact reinains that substantial attachment is not always sufficient to deinonstrate availability for work even under this view.

\section{Impact of Requiring Only Substantial Remaining Attachment}

Although the legitimate goals of the prograin, generally, and of the availability requireinent, in particular, would seein well served by the modification proposed here, it is worthwhile to consider more fully the impact on the system of such a change.

Many claimants are allowed, even under current law, to restrict inaterially their availability. For example, claimants have always been permitted, for a reasonable time at least, to restrict their availability to their "custonnary" occupation. ${ }^{95}$ Thus, in the ordinary course of things, the change advocated here will not affect an auto mechanic, who restricts acceptable einployment to work as an auto inechamic. Claimants have also been allowed to place geographic limits on acceptable work. Thus, if an individual chooses to seek work in only one of a number of "suitable" locales, the department permits the claimant to do so if the

93. Some readers may have difficulty conceptualizing a system, such as that proposed here, where individuals are permitted to proclaim their unavailability for work one day, but may be forced to accept the same work the next day. In considering this problem, it is important to remember that, but for such a refusal, the individual would be reemployed (or, if it is only a refusal of a referral, the claimant would have at least been referred to an actual job opening). A lard offer is more than a nonfunctional hoop through whicl claimants must jump, sometlimg that the availability requirement becomes when it goes beyond substantial attachment.

94. R. Altman, supra note 4, at 109. See Sancliez v. Unemployment Ins. Appeals Bd., 20 Cal. 3d 55, 71 n.17, 569 P.2d 740, 751 n.17, 141 Cal. Rptr. 146, 157 n.17 (1977) ("The purpose of the availability requirement is to insure a willingness to accept suitable work, not to tie a claimant to a previous occupation."); Freeman, supra note 4, at 126.

95. R. Altman, supra note 4, at 167. See P-B-200; P-B-196. Altman notes that factors determinative im particular cases imclude "the worker's age and how long le has been engaged in sucl employment, union affiliations, work prospects, and length of unemployment." R. ALTMAN, supra note 4, at 167 (footnote ouritted). 
chosen locale demonstrates that "the claimant is ready, willing and able to accept some substantial and suitable work."96

At first blush, costs appear likely to increase under the proposed change because fewer demals of benefits based upon unavailability can be expected. This in fact is unlikely because substantial contimuing attachment to the labor force by definition suggests a significant likelihood of reemploynient; a reduction in a worker's attachment does not necessarily imply a longer period of unemployment. On the other hand, administrative costs may be reduced because less time need be spent imvestigatimg and analyzimg claimants' personal circumstances to determine whether they have good cause for any reductions in their availability in a given situation.

Simce the proposed liberalization will affect a wide range of claimants, it is likely to have at least some impact on program administration. Two major issues in this respect are (a) the bureaucratic task of analyzimg the substantiality of current labor force attachment in particular cases, and (b) the coordination of these determinations with those regarding the sufficiency of individual searches.

\section{a. Analysis of "Substantial" Attachment}

Under Sanchez, it is of course true that the department already has the task of analyzing the extent of attachment of any claimant with good cause restrictions on acceptable employment to determine whether such attachment is "substantial."97 But that case still leaves the department free to look only at the reduction in attachment of those claimants without good cause for their restrictions. Hence, allowing all claimants to impose restrictions subject only to the substantial remaining attachment test may impose soniewhat greater burdens on the department to the extent that analyzing the remaining market is nore difficult than analyzing the reduction caused by particular restrictions.

Yet in order to determine whether a particular reduction is material, the department must look at the broader picture, analyzing to some degree the full range of employment opportunities that are suitable for the individual. Thus, if a claimant's restriction would reduce the range of suitable employnient by one major employer, this will be material to the claimant whose entire market consists of only two or three such employers, while the reduction might not be niaterial where the market consists of perhaps one hundred such employers.

The point is that the data that the department inust analyze in

96. Bliley Elec. Co. v. Unemployment Comp. Bd. of Review, 158 Pa. Super. 548, 561, 45 A.2d 898, 905 (1946).

97. Indeed, the department has the burden of proof on this issue in contested cases. Sanchez v. Unemployment Ins. Appeals Bd., 20 Cal. 3d 55, 70-71, 569 P.2d 740, 750-51, 141 Cal. Rptr. 146, 156-57 (1977). 
either case is to a large extent the same. The question remains, however, whether judging the data with respect to the remainimg market is more difficult. This is obviously an empirical question, but as the department has long had experience in making such determmations, the burden is not one of learning a new skill; at the most, a more detailed or extensive analysis may be necessary in close cases. ${ }^{98}$ In any event, the values served by making determinations appear to outweigh any incidental additional burdens on the departinent.

\section{b. Administration of the Work-Search Requirement}

As discussed earher, ${ }^{99}$ all claimants are subject to the work-search requireinent of the Unemployment Insurance Code. In considering the adoption of the analysis suggested in this Comment, it is fair to ask whether the new approach will cause any untoward difficulties im the administration of this requirement. There does not seem to be any reason to believe that it would. As long as an individual is attached to a substantial labor market and makes all reasonable efforts (as measured by current department standards) to find einployinent in that market, the requirennent should be satisfied. Thus, the sufficiency of the worksearch, insofar as the type of einployinent is concerned, will be analyzed in terms of the substantiality of the attachment.

A recent case, probably decided incorrectly under both pre- and post-Sanchez law, serves to illustrate how the availability and worksearch requirements may be applied together. In $U A W v$. California Department of Human Resources Development, ${ }^{100}$ ten auto workers were laid off during retooling at a General Motors plant. They were given specific recall dates which, depending upon the individual employee, were anywhere froin two to four weeks subsequent to the date of layoff. ${ }^{101}$ Upon applying for uneinployinent compensation benefits, the workers were each given seek-work plans which simply "required that the individuals register weekly with the departinent." 102 All of them left Califorma for various personal reasons. The departinent and trial court denied benefits to the claimants for the periods during which

98. Courts may have to scrutinize the department somewhat to determine that the concept of "substantial attachment" is not apphed in a stricter manner to clannants without good cause for their restrictions, as compared with those who do have good cause. In other words, the department ought not be able to apply the "substantial" test in such a way that it can more readily deny benefits to claimants who do not have good cause for their restrictions, but who nevertheless would be considered "substantially attached" as that term is imterpreted today. Similarly the department ought not be able to apply any stricter test of substantiality than it does today, even across the board, in an attempt to circumvent the more liberal rule proposed here.

99. See text accompanying and notes 50-56 supra.

I00. 58 Cal. App. 3d 924, 130 Cal. Rptr. 368 (2d Dist. 1976).

101. Id at $927,130 \mathrm{Cal}$. Rptr. at 369.

102. Id at 928 n.3, 130 Cal. Rptr. at 370 n.3. These claimants were given Seek-Work Plan "C," which is discussed at note 56 supra. 
they were out of the state, ${ }^{103}$ on the grounds that they were "unavailable" at those times. ${ }^{104}$

The court of appeal affirmed, distinguishing a ruling of the board in In re Gosh $a^{105}$ that had granted benefits to a claimant who had left the state to visit a bereaved aunt. Prior to his departure, Gosha had made arrangements with his hiring hall so that he could receive notice of job openings and could accept employment within twenty-four hours of such notification. The court noted that the combination of a specific statutory provision covering deaths in the immediate family, ${ }^{106}$ and the "claimant's ability and intent to return within 24 hours of notification of work ... satisfied the reasonable requirements of the act."107 The court, however, refused to accept the board's declaration in Gosh $a^{108}$ that an essential element of the inquiry into a claimant's eligibility is whether or not a potential job opportunity was lost. ${ }^{109}$ In doing so, the court distinguished two cases ${ }^{110}$ that held such proof might be necessary, on the ground that they involved subjective determinations by the department as to whether the claimants' appearances were unacceptable to employers. ${ }^{111}$

It is difficult to find any rationale for requiring claimants with definite recall dates to be "available," even under current standards. ${ }^{112}$ While it is true that the department will require individuals to search for, and be available for, work in other than their "custoniary" occupations, it is also true that such extended searches are not required where "good prospects exist for obtaining employment in [their customary]

103. The court of appeal asserted that the case did not turn on the interstate nature of the claimants' travel, but rather on the failure to report weekly to the department because they were out of the local area, id. at 932, 130 Cal. Rptr. at 373.

104. Id. at 928, 931, 130 Cal. Rptr. at 370, 372.

105. P-B-260.

106. See CaL. UNEmP. INs. Code § 1253.12 (West Supp. 1978), amending $§ 1253.1$ (a) (West 1972). The earlier version was in effect at the time $U A W$ went to trial.

107. 58 Cal. App. 3d at 932, 130 Cal. Rptr. at 373 (emphasis in original).

108. P-B-260 at 5 .

109. 58 Cal. App. 3d at 932, 130 Cal. Rptr. at 373. See BDG, supra note 47, at AA 5-21, which adopts a very limited "no lost work opportunity" rule.

110. The two cases are Cliambers v. Uneinployment Ins. Appeals Bd., 33 Cal. App. 3d 923, 109 Cal. Rptr. 413 (1st Dist. 1973), and Spangler v. Uneinployment Ins. Appeals Bd., 14 Cal. App. 3d 284, 92 Cal. Rptr. 266 (Ist Dist. 1971).

111. UAW v. California Dep't of Hunian Resources Dev., $58 \mathrm{Cal}$. App. 3d at 931, $130 \mathrm{Cal}$. Rptr. at 372. Future claimants inay benefit as a result of the court's decision not to further narrow the scope of those cases'from the realm of "subjective determinations" and limit them only to situations where fundamental constitutional rights are imphcated (e.g., in Chambers and Spangler, the first amendinent right of freedoin of expression was involved).

112. This seems supported by the $U A W$ court's acknowledgement of the department's determination in that case that "weekly registration was sufficient to satisfy the seek-work requirement because the individuals were only temporarily unemployed and were expected to return to work for their same employer in the near future." 58 Cal. App. 3d at 928 n.3, 130 Cal. Rptr. at 370 n.3. 
occupation within a reasonable time."113 Indeed, if Gosha is accepted-as it should be-then it is difficult to argue that the $U A W$ claimants could be disqualified for failure to make a proper search. Whereas Gosha simply "sought" work through his hiring hall, these claimants had already "found" employment.

It is also worth considering that claimants with definite prospects of work, such as those in $U A W$, who refuse offers of work apparently would have "good cause" for doing so on the basis of those work prospects. ${ }^{114}$ Thus, even under the Sanchez test, such individuals would be "available"-they certainly could refuse all offers of employinent that would require work beyond their limited lay-off period. Requiring many of such claimants to search for work therefore does not serve any purpose other than claimant harrassment. ${ }^{15}$

The analysis in these situations can be simplified by considering, pursuant to the approach suggested in this Comment, whether claimants, such as those in $U A W$, are "substantially attached." A definite einployinent arrangement set to commence reasonably soon demonstrates in itself substantial current attachment. If so, such claimants need not be available for any further work. It then follows that they do not have to search for any further work. Claimants with definite offers are "available" for work.

It is thus possible, within the current statutory framework, for the department to avoid requiring these claimants to jump through this nonfunctional hoop. The statute literally requires reasonable worksearch efforts, ${ }^{116}$ registration and reporting for work, ${ }^{117}$ and, of course, continued availability. ${ }^{118}$ Although a statutory provision directing exemption froin these requirements for individuals with reasonably near recall dates would be simpler, the current provisions, especially in light of Sanchez, support (and may require) such an "exemption." It is reasonable to make no work-search in such cases. ${ }^{119}$ Similarly, just as

113. BDG, supra note 47 , at AA § 510.1-2.

114. Id. at SW 365-1. The UAW court's justification for its result, that the claimants' physical availability allows for referral or dispatch to employers in need of their labors, thus seems to be misplaced.

115. This holds true for those individuals who fall within the rule regarding definite prospects near enough in the future to qualify for Seek-Work Plan "C." See note 56 supra. By applying the same standards as those used in the past to determine the appropriateness of Plan " $\mathrm{C}$," new administrative difficulties could be avoided.

116. Cal. Unemp. INS. Code $\$ \S 100,1253$ (e) (West 1972).

117. Id. \& 1253(b).

118. Id. \& 1253(c).

119. This is only another step in the direction of earker efforts by the department, through the various seek-work plans, to make each individual's search truly reasonable. Whenever claimants are forced to inake efforts that would go beyond those required to demonstrate substantial attachment, such efforts could be said to be unreasonable. It is here that the seek-work and availability requirements are related. If an individual engages in seek-work efforts that are so restricted that they do not represent substantial attachment, the individual would not be available under 
reporting to the department for possible work is waived in Seek-Work Plan " $\mathrm{B}$ " for mdividuals for whom the union hiring hall is the source of employment in their customary field, it should be waived for claimants with specific recall dates in the near future. ${ }^{120}$ Indeed, such recall dates provide a more definite source of reemployınent. Finally, determining the precise limits of the term "available" in different circumstances seems to be clearly within the discretion of "the director."121 Thus, the department ought to examine each case to determine whether or not the job prospects of a given claimant are such that using traditional availability criteria will merely harass the claimant.

\section{CONCLUSION}

Application of the availability requirement in a number of situations has proved to be no more than a penalty for not neeting the subjective expectations of the department. At the least, a moral judgment of the worthiness of a particular claimant's reason for job market restrictions slould not be made; ${ }^{122}$ to preserve claimant dignity, all claimants should inerely be tested on the basis of their attachment to the labor force. Whether demonstrated by a particular job offer or recall date, or by willingness to accept work in a "substantial" field of employment, substantial labor force attachment slould be the broad test. ${ }^{123}$ Certainly, the "material reduction" test is not in any way related to the question of whether an individual is attached to the labor

Sanchez. Thus, willingness to accept work is not thought sufficient if the claimant is unwilling also to seek it. Conversely, if the claimant meets the seek-work requirement by searching in a substantial labor market, that claimant should be viewed as available.

In this way, the Sanchez goal of harmonizing all measures of current attachunent is furthered by limiting the contours of the seek-work provision to those of the work-refusal provision. Claimants should not be denied benefits for failing to seek (or report/register for) work that they could not be forced to accept were it offered. More generally, while coerced seek-work efforts may be justifiable to the extent that they assure substantial labor force attachinent and induce "proinpt reeinployment in suitable work," 22 CAL. AD. CODE § 1253(c)-1 (1978) [see P-B-235], they are not justifiable when forced beyond that level.

120. See note 115 supra. Of course, such claimants should be expected to respond to changes in their recall dates, absent contractual imderstandings to the contrary.

121. See Cal. Unemp. Ins. Code $\$ 1253$ (West 1972).

122. In order to reduce the presuinption of fault, some inight argue that the initial quahifying conditions ought to be stricter. Cf. JOINT INTERIM COMM. REPORT, supra note 49, at 8 (recoinmending that Califormia adopt more stringent qualifying requirenients). Thus the program would be limited to those individuals who have inore solidly demonstrated that they are attached to the labor force, and who can be assumed to continue their attachunent. The social insurance ideals could thus be better protected. The danger, of course, is that a great number of attached, lowincome workers might be cut out of the program.

123. Thus, until the passage of time and the exhaustion of prospects in that field lave occurred (with a parallel lessening of any claim of attachunent based on that field), availability and search in that area should be deemed sufficient to qualify; the department should not investigate the claiunant's reasons for excluding other areas, at least in the absence of an actual job referral. 
[Vol. 66:1293

force; this test, and thus the notion that good cause is necessary to justify such a reduction, should be abolished.

Jim Dorskind*

* A.B. 1975, Cornell University; J.D. 1978, Boalt Hall School of Law, University of California, Berkeley; menıber, California Bar. 